\title{
KEPEMIMPINAN KYAI \\ DALAM PENGASUHAN PESANTREN
}

Mukhroji

Dosen Luar Biasa Sekolah Tinggi Agama Islam Negeri Purwokerto

\begin{abstract}
Islamic boarding schools as an educational institution with a total distinctive personality, always gives the freedom to determine the dynamic pattern of education policy. Kyai's (Islam cleric) leadership who dared to hold an educational innovation makes the boarding schools as a barometer of Islamic education in Indonesia. Good leadership is both acceptable to all parties and able to lead under God's guidance and to emulate the leadership of Prophet Muhammad based on akhlakul karimah (good attitude) and good habit (commendable) as siddiq, amanah, tabligh and fathonah.

Keyword: Leadership, clerics, schools, and innovation.
\end{abstract}

\section{Pendahuluan}

Pesantren sebagai lembaga pendidikan dengan totalitas kepribadiannya yang khas, selalu memberikan kebebasan untuk menentukan pola dinamis kebijaksanaan pendidikannya. Sehingga setiap tawaran pengembangan, baik berupa transfer dari luar (non pesantren) maupun atas prakarsa sendiri, tentunya akan melalui sektor pertimbangan dari dalam pesantren sendiri, yaitu pertimbangan tata nilai yang telah ada dan berlaku di pesantren selama ini (Mahfudh, 2004: 334).

Dewasa ini pesantren dihadapkan pada banyak tantangan, termasuk di dalamnya modernisasi manajemen sumber daya manusia di pesantren. Dalam banyak hal, sistem dan kelembagaan pesantren telah dimodernisasi dan disesuaikan dengan tuntutan zaman sekarang demi meningkatkan mutu dan pengembangan pesantren di masa yang akan datang. Ditilik dari sejarah pendidikan Islam Indonesia, pesantren sebagai sistem pendidikan Islam tradisional telah memainkan peran cukup penting dalam membentuk kualitas sumber daya manusia Indonesia. Pesantren sebagai 
lembaga pendidikan Islam tertua di Indonesia, akhir-akhir ini menarik untuk dicermati dan dikaji kembali terutama segi manajemen dan pola kepemimpinan Kyai dalam pengasuhan pesantren.

Kita mafhum bahwa pesantren lekat dengan figur Kyai ( Buya di Sumatera Barat, Ajengan di Jawa Barat, Bendoro di Madura, dan Tuan Guru di Lombok). Bila pesantren tidak ada Kyainya, bukan dinamakan pesantren, tetapi bisa saja lembaga pendidikan Islam atau yang lain. Sebab menurut Zamakhsyari Dhofier, pesantren memiliki lima elemen pokok, yaitu : kyai, santri, masjid, pondok, dan pengajaran kitab-kitab Islam klasik (Dhofier, 1994: 44). Kelima elemen tersebut merupakan ciri khusus yang dimiliki pesantren dan membedakan antara pendidikan pondok pesantren dengan lembaga pendidikan Islam bentuk lain. Walaupun kelima elemen ini saling menunjang eksistensi yang lain, akan tetapi kyai memainkan peranan yang begitu sentral dalam pesantren.

Keberadaan seorang kyai dalam lingkungan sebuah pesantren laksana jantung bagi kehidupan manusia dan merupakan figur sentral, otoritatif, pusat seluruh kebijakan dan perubahan pesantren. Intensitas kyai memperlihatkan peran yang otoriter disebabkan karena kyai-lah perintis, pendiri, pengelola, pengasuh, pemimpin, dan bahkan juga pemilik tunggal sebuah pesantren. Oleh sebab alasan ketokohan kyai di atas, maka banyak pesantren yang akhirnya bubar lantaran ditinggal wafat kyainya. Sementara kyai tidak memiliki keturunan yang dapat melanjutkan perjuangannya.

Sebagai salah satu unsur dominan dalam kehidupan sebuah pesantren, kyai mengatur irama perkembangan dan kelangsungan kehidupan pesantren dengan keahlian, kedalaman ilmu, karismatik, dan ketrampilan yang dimilikinya. Yang menjadi persoalan adalah bagaimana kepemimpinan kyai dalam pengasuhan pesantren di zaman modern ini.

\section{Seluk-Beluk Kepemimpinan}

Menurut para pakar manajemen, sebagaimana diungkapkan oleh Mundzier Suparta dan Amin Haedari (Mundzier, 2003:23-24) bahwa kepemimpinan menurut Duke adalah sebagai fenomena gestalt, yakni keseluruhan lebih besar daripada bagian-bagiannya. Menurut Dubin, kepemimpinan terkait dengan penggunaan wewenang dan pembuatan keputusan. Sementara Fiedler lebih melihat pemimpin sebagai 
individu dalam kelompok yang diberi tugas untuk mengarahkan dan mengkoordinasikan aktifitas-aktifitas kelompok yang terkait dengan tugas. Memperkuat pandangan ini, Stogdill menjelaskan kepemimpinan sebagai proses mempengaruhi aktifitas kelompok dalam rangka penyusunan tujuan organisasi dan pelaksanaan sasaran. Dan Pondy mendeskripsikan kepemimpinan sebagai kemampuan untuk menjadikan suatu aktifitas bermakna, tidak untuk merubah prilaku namun memberi pemahaman kepada pihak lain tentang apa yang mereka lakukan.

Dari beberapa pandangan para ahli manajemen di atas, nampak bahwa terdapat banyak pendekatan untuk memahami kepemimpinan tergantung perspektif apa yang digunakan. Hal ini tercermin dalam kata kunci yang ditonjolkan seperti, penggunaan wewenang (Dubin), tugas mengarahkan (Fiedler), mempengaruhi aktifitas (Stogdill), dan membuat aktifitas bermakna (Pondy). Dengan demikian, masing-masing mencerminkan corak pemimpin yang berbeda dalam latar dan kebiasaan. Secara pasti, tidak ada pemimpin pesantren yang seragam, masing-masing memiliki style / gaya yang berbeda.

Adapun implikasi kepemimpinan bagi pesantren, pada prinsipnya suatu lembaga pendidikan (pesantren) mensyaratkan adanya tipe pemimpin dan kepemimpinan yang khas. Dalam era modernisasi sekarang dibutuhkan kepemimpinan yang mampu memberdayakan masyarakat pesantren dengan tanpa mengorbankan ciri khas atau kredibilitas pengasuh pesantren (kyai). Dalam pesantren, kepemimpinan dilaksanakan di dalam kelompok kebijakan yang melibatkan sejumlah pihak, di dalam sebuah tim program, di dalam organisasi ustadz, wali santri dan santri. Kepemimpinan yang membaur ini menjadi faktor pendukung aktifitas sehari-hari di lingkungan pesantren.

Dalam mengkaji masalah kepeimpinan Kyai, kita menggunakan pendekatan sosiologis-normatif. Dengan pendekatan tersebut, aspek-aspek yang melekat pada konstelasi kepemimpinan Kyai terhadap santrinya bisa secara menyeluruh. Kyai adalah manusia biasa yang memiliki kelebihan dan kekurangan, dan kelak akan dimintai pertanggunganjawabnya oleh Allah SWT berkenaan dengan aplikasi kepemimpinannya. Dalam hal ini, Allah SWT telah memberikan etika agama agar dijadikan sebagai sumber nilai oleh Kyai. Kalau Kyai benar-benar menjalankan mekanisme 
kepemimpinan sesuai dengan etika agama, sudah pasti dapat membawa implikasi positif bagi pesantren khususnya dan masyarakat pada umumnya. Secara sosial-politik, Kyai wajib memerankan dirinya sebagai pelindung umat, bukan malah menciptakan kesulitan (masalah). Semua ketentuan itu merupakan kewajiban moral dan dibakukan oleh ajaran normatif, serta telah dipahami oleh masyarakat sebagai ketentuan yang harus dilaksanakan oleh Kyai (Zubaidi , 1996: 35).

Kepemimpinan adalah suatu kekuatan penting dalam rangka pengelolaan pesantren. Oleh sebab itu kemampuan memimpin secara efektif seorang Kyai merupakan kunci keberhasilan dalam pengelolaan pesantren. Esensi kepemimpinan adalah kepengikutan kemauan orang lain untuk mengikuti keinginan pemimpin. Menurut Abdullah Gymnastiar, kepemimpinan itu adalah suatu ketrampilan. Dia butuh terus menerus suplai ilmu dan melatih diri. Menurutnya pula, bahwa siapapun pemimpin yang tidak banyak belajar, tidak banyak berlatih, tidak meluaskan wawasan, maka dia tidak akan bisa menjadi pemimpin yang trampil. Yang dibutuhkan dalam sebuah organisasi (pesantren), yang terpenting bukan kebersamaan, tetapi komitmen dan terikatnya hati. Kekuatan kepemimpinan adalah tidak adanya jarak antara hati seorang pemimpin dengan yang dipimpinnya (Gymnastiar, 2001: 21). Jadi kedekatan hati antara Kyai dan santri merupakan suatu kekuatan yang sangat menentukan keberhasilan pesantren dalam meningkatkan mutu pendidikan pesantren yang diimbangi dengan kepemimpinan (ketrampilan) Kyai dalam mengelola atau mengasuh pesantren.

Kepemimpinan sebagai salah satu fungsi manajemen merupakan hal yang sangat penting untuk mencapai tujuan pesantren. Dengan amat berat seolah-olah kepemimpinan dipaksa menghadapi berbagai macam faktor seperti : struktur atau tatanan, koalisi, kekuasaan, dan kondisi lingkungan pesantren. Sebaliknya kepemimpinan rasanya dapat dengan mudah menjadi satu alat penyelesaian yang luar biasa terhadap persoalan apa saja yang sedang menimpa pesantren.

Ada beberapa tipologi kepemimpinan yang dapat dijadikan sebagai acuan dan pertimbangan bagipengasuh pesantren dalammelaksanakan tugas kepemimpinan di lingkungan pesantren masing-masing (Mundzier, 2003: 25-45).: 1) kepemimpinan kultural pesantren, 2) kepemimpinan strategik 
pesantren, 3) kepemimpinan pendidikan pesantren, 4) kepemimpinan transformatif, 5) kepemimpinan responsif, dan 6) kepemimpinan edukatif.

Dalam sejarah, terdapat pemimpin yang berlaku sewenang-wenang, dengan alasan bahwa ia adalah wakil Allah di bumi. Namun di sini ia sangat keliru dalam memahami dan mempraktekan bentuk hubungan kepemimpinan Islam. Hubungan antara pemimpin dengan bawahan bukan merupakan hubungan antara penakluk dan yang ditaklukan, atau antara tuan dengan hamba. Tetapi di sini adalah hubungan kebersamaan dalam ketundukan kepadaAllah SWT. Sebab walaupun seorang pemimpin mampu menguasai bawahannya, namun hal tersebut bukan akibat kekuatan yang dimilikinya. Tetapi karena Allah telah menundukkannya bagi manusia. Hal ini antara lain tergambar dalam firman Allah surat Ibrahim ayat 32 dan surat Az-Zukhruf ayat 13. Karena itu, kepemimpinan Kyai menurut Al-Qur'an menuntut adanya interaksi antara manusia dengan sesamanya sesudah dengan petunjuk-petunjuk Ilahi yang tertera dalam wahyuwahyu-Nya. Semua itu harus ditemukan oleh Kyai sambil memperhatikan perkembangan dan situasi lingkungan. (Zubaidi , 1996: 35-36).

\section{Syarat-syarat Pribadi Pemimpin}

Kyai adalah seorang pemimpin yang diberi wewenang oleh Allah untuk membimbing dan membina umat Islam, namun dikhawatirkan komitmennya oleh Malaikat seperti terungkap dalam QS. Al - Baqarah (2) : 30. Memang tidak menutup kemungkinan ada Kyai yang berani menyalahgunakan wewenang Allah, suka menekan umat dan bertindak di luar batas. Kyai diangkat salah satunya karena faktor pengakuan dari masyarakat. Dan untuk dapat memberikan pengakuan pada Kyai, mesti ada beberapa syarat yang harus dipenuhi. Karel A. Steenbrink menulis (Steenbrink, 1994:109):

"Dalam masyarakat tradisional, seseorang dapat menjadi Kyai atau disebut Kyai karena ia diterima masyarakat sebagai Kyai,.....Memang untuk menjadi Kyai tidak ada kriteria formal seperti persyaratan studi, ijazah dan sebagainya. Akan tetapi ada beberapa syarat non-formal untuk menentukan seseorang menjadi Kyai besar atau kecil". 
Menurut H. Abu Bakar Atjeh, sebagaimana yang dinukil oleh Zubaidi ada beberapa faktor penyebab seseorang menjadi Kyai yaitu: pengetahuannya, kesalehannya, keturunannya dan jumlah murid (yang terakhir khusus untuk Kyai besar). Vre den Berg memberikan ketentuan yang hampir sama dengan Abu Bakar Atjeh, yakni : keturunan, pengetahuan agama, jumlah murid dan cara dia mengabdikan dirinya pada masyarakat (Zubaidi , 1996: 40). Lebih lanjut Zubaidi mengatakan bahwa kelebihan seorang Kyai tidak untuk disombongkan atau dijadikan alat untuk mendominasi dan menekan umat atau santri, akan tetapi hendaknya kelebihan itu dijadikan untuk saling mengisi dan membantu satu sama lain. Karena itu, secara normatif menurutnya, Kyai dituntut untuk selalu berusaha menegakkan aqidah, syari'ah dan moral, agar segala kelebihan dirinya tersebut mampu dipertahankan sesuai nilai-nilai agama serta sanggup menjadi suri tauladan yang baik dan benar bagi santrinya.

Ada syarat tambahan yang harus dipenuhi oleh Kyai dalam memerankan dirinya sebagai pemimpin umat:

Pertama, dapat menggunakan kekuasaan yang benar. Artinya, kekuatan, otoritas dan legalitas kepemimpinannya harus ditunjukkan untuk mempengaruhi dan menggerakkan umat atau santri agar berbuat sesuatu yang baik dan bermanfaat.

Kedua, memiliki kewibawaan, yaitu kelebihan, keunggulan, keutamaan, sehingga Kyai mampu mengatur, sementara mereka yang diatur patuh dan taat kepada Kyai.

Ketiga, kemampuan leadership, ialah segala daya, kesanggupan, kekuatan dan kecakapan serta ketrampilan teknis maupun sosial, yang dianggap melebihi kemampuan santri atau umat. (Zubaidi , 1996: 41).

Kewibawaan Kyai dan kedalaman ilmunya adalah modal utama bagi berlangsungnya semua wewenang yang dijalankan.Hal ini memudahkan berjalannya semua kebijakan yang diambil oleh Kyai, karena ia adalah sebagai tokoh kunci, kata-kata dan keputusannya dipegang teguh dan ditaati oleh santri maupun masyarakat lingkungan pesantren.

\section{Kyai dan modernisasi}

Tradisi pesantren memiliki sejarah yang sangat panjang. Indonesia sebagai negara yang banyak terdapat pesantren dan juga salah satu tempat 
konsentrasi umat Islam terbesar di dunia, mempunyai potensi yang besar bagi penentuan arah perkembangan Islam di seluruh dunia. Di samping itu Kyai-kyai di Jawa juga merupakan sektor kepemimpinan Islam yang dianggap paling dominan, dan selama berabad-abad telah memainkan peranan yang menentukan dalam proses perkembangan sosial, kultural, keagamaan dan politik.

Adanya kesimpulan yang keliru dari para penulis tentang Islam tradisional yang menyatakan bahwa para Kyai telah menjadi penghambat bagi lajunya proses modernisasi, disebabkan oleh dua hal, yaitu : 1) mereka mengira bahwa nilai-nilai spiritual yang dipegang dan dianjurkan oleh para Kyai tidak lagi relevan dengan kehidupan modern, dan 2) mereka mengira bahwa para Kyai tidak mampu menerjemahkan nilainilai spiritual tradisional tersebut bagi pemuasan kebutuhan-kebutuhan kehidupan modern, padahal di tengah-tengah gejolak pembangunan ekonomi di Indonesia dewasa ini, para Kyai tetap merupakan sekelompok orang-orang yang bersedia membangun kesejahteraan spiritual bangsanya. (Dhofier, 1994: 171-173).

Pesantren memang terikat kuat dengan formulasi eksplisit dari pada Islam tradisional. Tetapi para Kyai yang menjadi penghubung antara Islam tradisional dengan dunia nyata ini juga merupakan bagian dari kehidupan dunia. Kedudukan ganda Kyai ini memang unik, dan menjadi inti dari dari kualitasnya yang menonjol. Kedudukan ganda ini seringkali menyulitkan Kyai sebagai pimpinan pesantren dan menjadi sumber tragedi yang sering dialami Kyai, tetapi justru pada kedudukan ganda ini pula terletak kharisma mereka. Para Kyai adalah pemimpin-pemimpin yang kreatif yang selalu berhasil mengembangkan pesantren dalam dimensi-dimensi yang baru, dan panorama yang berwajah sangat majemik dari kehidupan pesantren sekarang ini, adalah merupakan petunjuk adanya kreasi yang jenius dari para Kyai.

\section{Kepemimpinan dan Suksesi Kyai}

Gaya kepemimpinan di pesantren terlihat bahwa kedudukan dan kekuasaan pimpinan-dalam hal ini sesepuh dan pembina pesantren-sangat kuat dan mantap, kendatipun gaya kepemimpinan yang ditampilkan oleh pesantren bersifat kolektif atau institusional. Hal ini disebabkan karena 
adanya tata nilai dalam kehidupan mereka, bahwa yang muda menghormati yang tua, santri menghormati Kyai dan ustadz, dan juga adanya irsyadul ustadz (petunjuk guru).

Hubungan antara santri, ustadz, pengurus dan Kyai adalah sebagaimana satu keluarga dalam rumah tangga, di mana Kyai dan Nyai (isteri Kyai) sebagai guru, bapak, ibu dan pemimpin mereka. Dan hubungan kerja kepemimpinan mereka dilandasi oleh sifat ikhlas, berkah dan ibadah. Tatanan kerja organisasinya dapat diketahui dengan jelas, pembagian tugas antar unit kerja dapat dipisahkan dengan tajam. Masing-masing pimpinan unit kerja bebas berinisiatif dan bekerja untuk kemajuan dan kebaikan pesantren. Selama apa yang mereka lakukan tidak bertentangan dengan misi pondok, dan memperoleh restu Kyai atau setidak-tidaknya diperbolehkan atau tidak dilarang oleh Kyai, maka selama itu pula pekerjaan boleh diteruskan. Berkenaan dengan itulah, maka gaya kepemimpinan di pesantren memiliki ciri paternalistik, dan free rein leadership, yang dalam hal ini pemimpin bersifat pasif, sebagai seorang bapak yang memberikan kesempatan kepada anak-anaknya untuk berkreasi, tetapi juga otoriter, yaitu memberikan kata-kata final untuk memutuskan apakah karya anakanaknya (santri) yang bersangkutan dapat diteruskan atau harus dihentikan. (Mansur, 2004: 49-51).

Ada beberapa teknik pengambilan keputusan yang dapat dilakukan oleh Kyai. Sebab pengambilan keputusan dapat dipandang sebagai tolok ukur utama dari kinerja seorang pemimpin pesantren. Semua hasil keputusan pemimpin pesantren akan menjadi acuan berfikir, bersikap dan berbuat bagi kominitas pesantren. Oleh karena itu, Kyai sebagai figur sentral pesantren perlu menggali prinsip, konsep, dan teknik pembuatan keputusan pendidikan yang terus berkembang. Dan karena kepemimpinan pesantren bersifat unik, berbeda dengan pengambilan keputusan yang dilakukan oleh oleh lembaga formal yang cenderung rasional-ilmiah, maka teknik pembuatan keputusan di pesantren lebih bersifat emosionalsubyektif. Para Kyai tidak akan tergesa-gesa dalam mengambil keputusan terhadap suatu masalah. Mereka tidak hanya mempertimbangkan secara nalar, namun diikuti oleh gerakan hatu nuraninya yang paling dalam, tawasul kepada gurunya, dan tidak lupa menyandarkan secara vertikal munajat untuk beristikharoh kepada Allah SWT. Gaya pengambilan 
keputusan ini lebih mendasarkan kepada budaya khas pesantren dan masih melekat dalam gaya kepemimpinan Kyai pesantren di tanah air. Mundzier , 2003: 46).

Dalam era modern ini, ada baiknya para Kyai sebagai pemimpin dan pengasuh pesantren berupaya untuk meningkatkan mutu pendidikan pesantren berdasarkan perspektif global dengan memandang manajemen pesanren sebagai bagian dari urusan duniawi (mu'amalah) yang menuntut prilaku rasional. Oleh karena itu, alangkah baiknya para Kyai atau pemimpin pesantren mau mengkaji beberapa teori atau model pembuatan keputusan yang lazim dilakukan di dalam organisasi modern. Dengan melihat model pembuatan keputusan pendidikan tersebut, mereka dapat mentransfer hal-hal positif untuk pembuatan keputusan pendidikan di pesantren yang mereka pimpin. Hal ini sebenarnya tidak menyimpang dari kaidah yang terkenal yang dipegangi pesantren, yaitu : al-muhaafadhatu 'alaa qadiimish-shaalih wal akhdzu bil jadiidil ashlaah, menjaga tradisi / warisan lama yang baik dan memingut inovasi-inovasi baru yang lebih baik.

Ada dua model pembuatan keputusan yang banyak digunakan dalam lembaga pendidikan formal, yaitu : 1) model klasik, dan 2) model administratif. (Mundzier , 2003: 47-50).

Petama, Model klasik berasumsi bahwa keputusan harus dibuat sepenuhnya secara rasional melalui optimalisasi strategi untuk mencari alternatif terbaik dalam rangka memaksimalisasi pencapaian tujuan dan sasaran lembaga. Langkah-langkahnya meliputi: (a) masalah diidentifikasi; (b) tujuan dan sasaran ditetapkan; (c) semua alternatif yang mungkin diinventarisasi; (d) konsekuensi dari masing-masing alternatif dipertimbangkan; (e) semua alternatif dinilai; (f) alternatif terbaik dipilih; dan (g) keputusan dilaksanakan dan dievaluasi. Model klasik ini terlalu ideal untuk diterapkan di pesantren, sebab membutuhkan sumber daya manusia yang berlatar belakang akademik.

Kedua, Model administratif diperkenalkan oleh Simon (1974) melalui riset untuk memberikan gambaran yang akurat tentang caracara kerja administrator dan pembuatan keputusan organisasi, yang berlandaskan pada asumsi : (a) proses pembuatan keputusan (decisionmaking process) merupakan siklus peristiwa yang mencakup identifikasi 
dan diagnosis terhadap suatu kesulitan, pengembangan rencana untuk mengatasi kesulitan, prakarsa terhadap rencana, dan penilaian terhadap keberhasilannya; (b) esensi administrasi (pendidikan) terletak pada kinerja proses pembuatan keputusan yang melibatkan individu atau kelompok dalam organisasi; (c) berfikir rasional yang sempurna dalam pembuatan keputusan adalah mustahil; (d) fungsi utama penyelenggaraan pendidikan adalah menyiapkan lingkungan yang kondusifbagi setiap anggota organisasi pendidikan untuk terlibat dalam pembuatan keputusan sehingga prilaku setiap individu di dalamnya rasional; (e) proses pembuatan keputusan merupakan pola tindakan yang umum terjadi dalam penyelenggaraan semua bidang tugas dan fungsi lembaga; (f) proses pembuatan keputusan berlangsung dengan bentuk generalisasi yang sama dalam organisasi yang kompleks.

Model pembuatan keputusan di pesantren dapat mengkombinasikan model-model keputusan di atas sesuai dengan situasi dan kondisi setempat. Selain itu dapat pula dikembangkan model pembuatan keputusan partisipatif yang dapat dijadikan acuan untuk meningkatkan pendidikan dan pengajaran di pesantren dengan melibatkan ustadz atau guru sebagai ujung tombak pendidikan pesantren. Dengan demikian, secara operasional keputusan partisipatif mengandung arti bahwa partisipasi ustadz /guru atau pihak lain dalam pembuatan keputusan sangat berarti dan besar pengaruhnya.

Suksesi kepemimpinan Kyai adalah sesuatu yang sangat menarik di lingkungan pesantren. Karena tidak semua keluarga Kyai dapat menggantikan kedudukannya. Dan biasanya estafet pergantian kepemimpinan yang ada di pesantren adalah turun temurun dari pendiri ke anak ke menantu ke cucu atau santri senior. Artinya, ahli waris pertama adalah anak laki-laki, yang senior dan dianggap cocok oleh Kyai dan oleh masyarakat untuk menjadi Kyai, baik dari segi kealimannya maupun dari segi kedalaman ilmu agamanya. Jika hal ini tidak mungkin, misalnya karena pendiri tidak punya anak laki-laki yang cocok untuk menggantikannya, maka ahli waris kedua adalah menantu, kemudian sebagai ahli waris ketiga adalah cucu. Jika semuanya tidak mungkin, maka ada kemungkinan dilanjutkan oleh bekas santri senior. Tetapi biasanya santri lebih suka mendirikan pesantren sendiri, dan bila hal ini terjadi maka berakhirlah 
pesantren yang bersangkutan karena tidak ada yang meneruskannya.

Suksesi kepemimpinan pesantren sebagaimana digambarkan di atas, tidak hanya berlaku bagi pondok pesantren yang berstatus sebagai yayasan, tetapi juga berlaku bagi pesantren-pesantren yang berstatus pribadi. Meskipun secara resmi suadah ada ketentuan bahwa ahli waris pendiri tidak dengan sendirinya menjadi pengganti. (Mansur, 2004: 5354)

\section{Penutup}

Kyai sebagai pemimpin pesantren harus mampu melakukan inovasi-inovasi pendidikan pesantren dalam usaha meningkatkan mutu pendidikannya. Dengan kepemimpinan Kyai yang responsif, transformatif, dan edukatif diharapkan pesantren mampu menjadi pendidikan alternatif atau unggulan di era modernisasi seperti sekarang ini.

Dengan gaya kepemimpinan Kyai yang beragam menjadikan pesantren menjadi unik dan menarik untuk dikaji dan dietliti demi pengembangan dan peningkatan mutu pesantren di masa datang.

Uraian di atas menunjukkan bahwa walaupun para Kyai terikat oleh pola pemikiran Islam tradisional, namun mereka telah mampu membenahi dirinya untuk tetap memiliki peranan dalam membangun masa depan Indonesia yang lebih baik. Mereka tidak mendambakan, apalagi melindungi pandangan hidup mereka yang tradisional tersebut menjadi suatu sistem yang tertutup dan memalingkan diri dari proses modernisasi. Sesungguhnya mereka telah berhasil memperbaharui penafsiran mereka terhadap Islam tradisional untuk disesuaikan dengan dimensi kehidupan yang baru, terutama dalam dunia pendidikan pesantren. Sehingga ke depan dengan kepemimpinan Kyai yang berani mengadakan inovasi-inovasi pendidikan pesantren menjadikan pesantren sebagai barometer pendidikan Islam di Indonesia.

Kepemimpinan yang baik adalah yang bisa diterima oleh semua pihak dan mampu memimpin dengan petunjuk Ilahi Rabbi dan meneladani kepemimpinan Rasulullah SAW yang di landasi oleh akhlakul karimah dan sifat-sifat mahmudah (terpuji) seperti siddiq, amanah, tabligh dan fathonah. 
Mukhroji

\section{DAFTAR PUSTAKA}

Asy'ari, H. Z. (1996). Moralitas Pendidikan Pesantren. Yogyakarta: LKPSM.

Gymnastiar, A. (2001). Manajemen Diri. Bandung: MQS Pustaka Grafika.

Mahfudh, S. (2004). Nuansa fiqih Sosial. Yogyakarta: LKiS.

Mansur, (2004). Moralitas Pesantren;Meneguk Kearifan daru Telaga Kehidupan. Yogyakarta: Safira Insania Press.

Suparta, M. (Ed.). (2003). Manajemen Pondok Pesantren. Jakarta: Diva Pustaka.

Steenbrink, A. K. (1994). Pesantren, Madrasah, Sekolah. Jakarta: LP3ES.

Zamakhsyari, D. (1994). Tradisi Pesantren; Studi tentang Pandangan Hidup Kyai. Jakarta: LP3ES. 